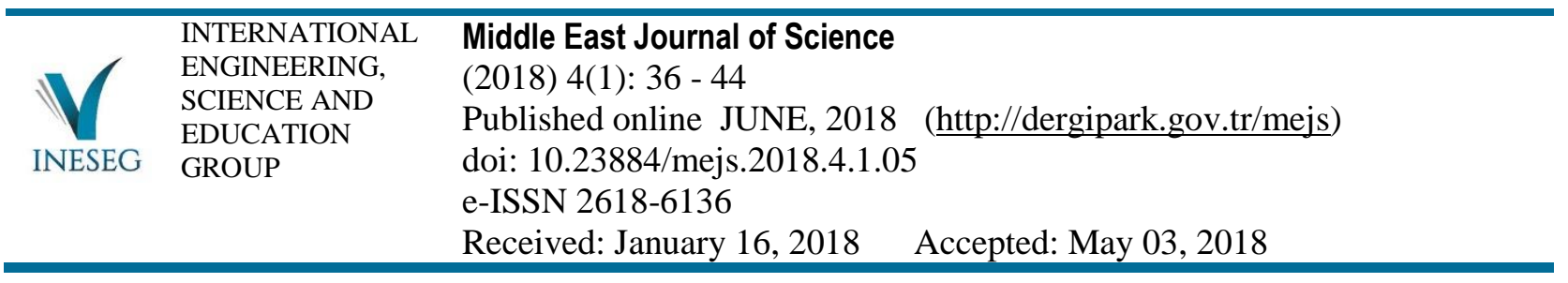

\title{
AN EXAMPLE TO THE CHANGE OF EARTH SHAPE: EVIDENCE OF TETHYS SEA IN DIYARBAKIR
}

\author{
İhsan EKİN ${ }^{l *}$, Rudvan ŞEŞEN ${ }^{2}$ \\ ${ }^{1}$ Department of Energy Systems Engineering, Faculty of Engineering, Şırnak University, Şırnak, \\ Turkey \\ ${ }^{2}$ Department of Biology, Faculty of Science, Dicle University, Diyarbakır, Turkey \\ *Correspondence: e-mail: ekinihsan@gmail.com
}

\begin{abstract}
The change of earth shape over time is expressed as Geological Evolution. The German meteorologist Alfred Wegener (1880-1930) describes the geological evolution of the Continental Drift Theory, which means that terrestrial parts of the earth and large water bodies change over time. According to the Continental Drift Theory, during the Mesozoic Era, the large earth continent Pangaea was divided into two gigantic continents (Laurasia and Gondwana), forming the Tethys Sea. The Tethys Sea was connected to the present Indian Ocean through the Atlantic Ocean and the Mediterranean Sea. A large part of Anatolia, especially in Southeastern Anatolia, was covered with the sea for a long time. Today's both the Mediterranean and the Black Sea is considered as a remnant of Tethys Sea. These seas were also subjected to some other important changes. In the studies carried out within the province of Diyarbakır, the biological evidence of the Tethys Sea was found in invertebrate fossils. The marine form of fossils belonging to Echinodermata and Bivalvia phyla are frequently encountered in the Southeastern Anatolia Region. They were collected from the Diyarbakur province and photographed. The fossil specimens are of great importance in terms of understanding the geological changes (Geological evolution) that the region has undergone over time.
\end{abstract}

Keywords: Diyarbakır, Tethys Sea, Invertebrate fossils,

\section{Introduction}

The concept of evolution essentially includes three sub-concepts: Inorganic Evolution, Organic Evolution, and Social Evolution [1]. Inorganic evolution studies the change of inanimate objects. In particular, it covers events from the formation of the universe to the formation of inanimate objects, which form the basis of living things. Some authors also use chemical and physical concepts of evolution for these changes over time. Geological Evolution is generally used for changes that take place in the forms of the earth $[2,3]$. In this work, we adopted this statement and used the expression "Geologic Evolution" as many scientists have used. The content of our work includes the geological change that our region has undergone with the presence of the fossil record. 
Organic evolution, however, examines the evolution of living things over time. The biological evolution that has begun from the moment when the first living things emerged (approximately 3.5 billion years ago) and still continues is the subject of the science of Biology in general. When it comes to evolution, it is generally desired to describe the Biological evolution and it is the most interesting concept of evolution. Social evolution examines the changes of societies over time. The change of societies over time is more a matter of sociology science. Changes are mostly on a cultural basis. In our work, it was thought that the use of "Geological Evolution" statement from the above-mentioned concepts of evolution is correct.

One of the most important theories about the transformation of the earth is the "Continental Drift Theory". This theory was first suggested by the German meteorologist Alfred Wegener in 1912, and the subsequent contributions bring in important benefits to the theory (Paleontological, geological and biological findings, and photographs taken from the space, seismic studies, and deep sea studies). According to this theory; at the beginning of the Mesozoic Era, all the earth continents were together in one piece. The Pangaea, large single continent, has been shattered throughout the Mesozoic Era and transformed into today's continents. Pangaea was first divided into the North and South continents. The north part is Laurasia; the southern part is called Gondwana. The sea of Tethys formed in the space between Laurasia and Gondwana. The name of Tethys Sea was first used by the Austrian geologist Edward Suess in 1893. Suess used this name based on the fossils of living creatures that existed only in the seas, both in the Alpine mountains and in parts of Africa at that time. This sea was thought more as an inner sea. Wegener used the term Tethys, however, explained the existence of the sea in a different way, according to the Continental Drift Theory. The sea of Tethys, as mentioned above, was linked to the Indian Ocean, covering a large part of today's North Africa and a large part of southern Europe and the Middle East on the Mediterranean Sea. In other words, it was a sea separating the two great continents, Gondwana and Laurasia. The sea of Tethys, formed by millions of years of change, has shrunk in time and has become almost an inland sea with its remains, like the Mediterranean. Once upon a time, when Anatolia was covered with the sea, due to the proximity of the African continent to the Asian and European continents, some island-shaped ascents have developed. Turkey, a young stratum, formed between Eurasia in the north and Africa-Arabia plates in the south [4]. This zone is occasionally covered with seas, depending on weather conditions and some other conditions. Southeastern Anatolia is finally assumed to be covered by the sea about 7 million years ago [5]. During the Era when Anatolia was covered with sea, some marine living creatures were preserved as fossils till today. 


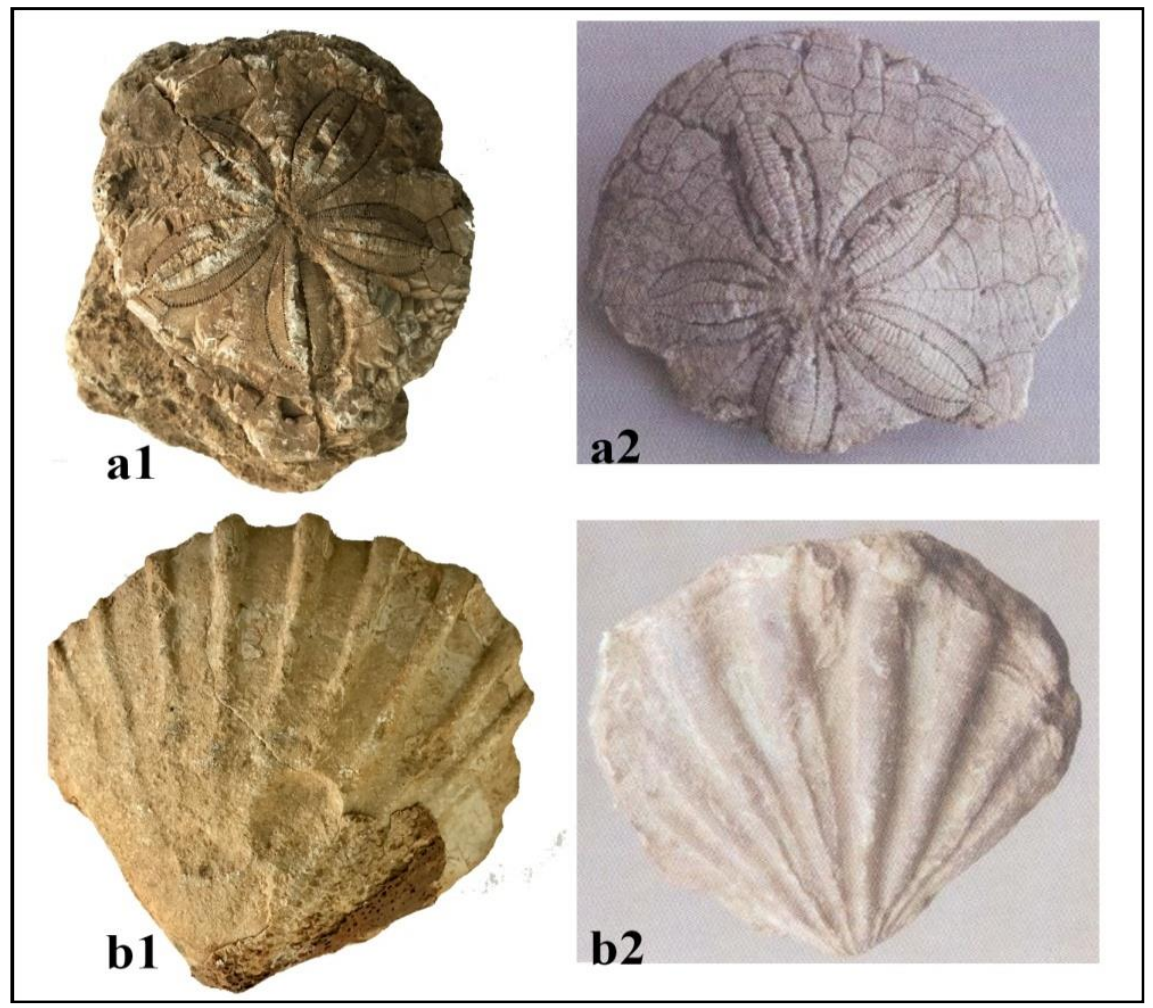

Photograph 1. a1. Clypeaster genus and b1. Flabellipecten genus, two fossils collected from the region between the Hani and Lice in Diyarbakir city. The photograph of these genera, which have already been recorded, is shown a2. Clypeaster tauricus and b2. Flabellipecten cf. fraterculus [4].

With the comparison of the photographs, the genera of the fossils are more or less understood. But it is not very accurate to say exact name of the species, a detailed investigation is required.

\section{Material and Method}

In order to be used in previous investigations, the fossil specimens were collected between 1990 and 2016 in Southeastern Anatolia region and brought to the laboratory of Biology Department. Fossils are found in the mountainous region between Lice and Hani district in Diyarbakır. The first fossils were identified at the phylum level. It is understood that the detected fossils generally belong to two important invertebrate phyla whose internal organs are covered with hard crust or interlocked plaques. The fossils were examined; their photographs were taken and maintained in the biology department for further studies. 


\section{Results}

The collected fossils were first identified according to their Phyla. Most of the fossils belong to the Echinodermata Phylum (Photograph a1) and some of them belong to Bivalvia class, Clypeaster genus (Photograph b1).

Echinodermata is one of the most important invertebrate phyla that enter the group of Deuterostomia, which is also consisting of vertebrates. For this reason, this phylum is described in many books after the arthropods. The most important feature of this phylum is that all species have been living in the seas from the beginning to the nowadays. And generally, show radial symmetry of 5 in mature form. This phylum, which is regarded as real marine animals, is examined in 5 classes; Sea lilies (Crinozoa), Sea stars (Asteroidea), Brittle stars (Ophiuroidea), Sea urchins (Echinoidea) and Sea Cucumbers (Holothuroidea) [6]. A significant quantity of the fossils collected from the Diyarbakir belongs to the class of Sea urchins (Echinoidea) of Echinodermata phylum. The five radial symmetry structure in the fossils is obviously seen. Another important feature of this phylum is their tube feet which are used for various purposes by the animal. The holes of tube feet (interambulacral regions) that come out from the plates of the feet (ambulacral regions) are visible in the fossils (Photograph 2a). The holes in the tube legs can be counted on the fossil specimen (Photograph 2b). Fossilization is not easy as is known. It requires very special conditions. The most important environments in fossil formations are clayey and muddy environments, especially composed of fine particles. The living thing that has fallen or drifted into this mud anyhow, the elements around it become hardened and become fossilized in a real form. Then, the shell or crust can often disappear with decay, but the shape of the organism remains constant. If the minerals then fill in this mold, a new mold is formed again and a moulage of the organism occurs and gives a general outline of the living thing. If the body mold is filled with the only mineral, it is called calcification [7]. Our examples are petrified fossils thought to be formed as described above.

Another part of the fossils belongs to Bivalvia class of Mollusca phylum. The vast majority of molluscs live in the seas, a significant amount in the land and a few of them dwell in freshwater. They are divided into seven classes; Aplacophora, Monoplacophopra, Polyplacophora, Scaphopoda, Gastropoda (Snails and slugs), Bivalvia (Mussels and oysters) and Cephalopoda (Octopuses, squid, and cuttlefish) [6].The first four classes live only in the seas and are represented by few species. The bivalves are an important mollusc class, mostly in the sea, and some forms live in freshwater.

There are no protrusions called carina on the shells of freshwater mussels. Most of the mussels living in the sea have these protrusions. In the fossil example in the photograph $2 \mathrm{c}$, the carina, ligament region and umbo part of the sea bivalve are clearly visible. There is no doubt that the fossil, which has carina, is a bivalve species living in the seas (Photograph 2c). These fossils are similar to those of today's living Flabellipecten genus. 


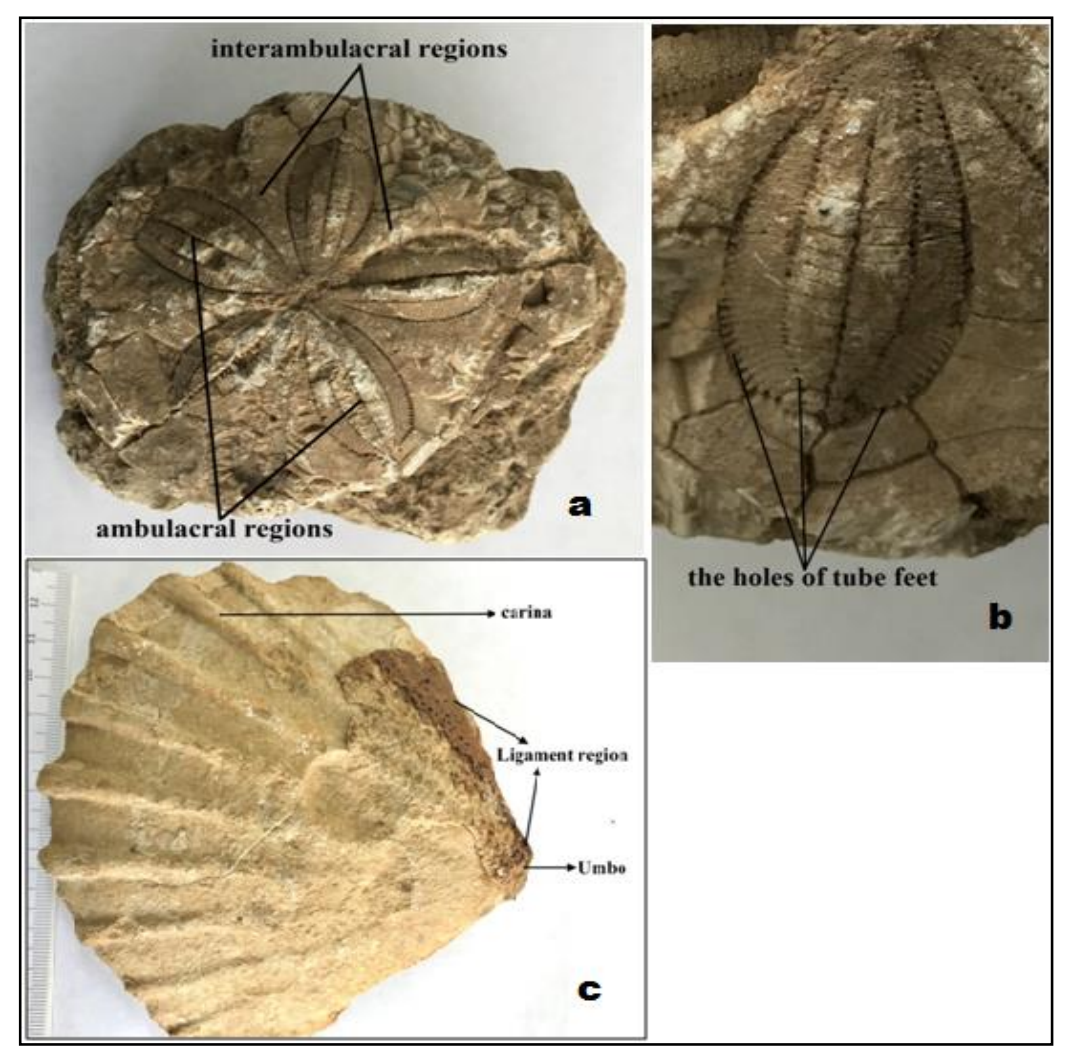

Photograph 2. a. Ambulacral and interambulacral regions on a Clypeaster fossil, b. The holes of tube feet in Clypeaster fossil, c. Carina, ligament and umbo regions in Flabellipecten fossil.

Table 1. The systematic of two fossil records, Flabellipecten and Clypeaster

\begin{tabular}{lll}
\hline Kingdom: & Animalia & Animalia \\
Phylum: & Mollusca & Echinodermata \\
Class: & Bivalvia & Echinoidea \\
Order: & Pterioida & Clypeasteroida \\
Family: & Pectinidae & Clypeasteridae \\
Genus: & Flabellipecten & Clypeaster \\
\hline
\end{tabular}

\section{Conclusions}

Turkey, in terms of marine fossils, includes very rich geological plates. For this reason, several researchers have focused on the fossil records of Turkey. In a study on Turkish fossil records, fifteen brachiopod species consisting of two new records (Paillettiamenaesp. nov. and Eodmitriasezgini sp. nov.) and three crinoid species, have been identified. This fossil assemblage reflects strong affinities with Gondwanan and peri-Gondwanan domains [8]. Anatolia's geological structure is the product of the continents' tectonic movement history because of the location at the intersection of Asia, Europe, and Africa. Turkey's basic rock structure has evolved through the subduction-collision process by combining and accumulating with the Gondwana disposition in the south and the Eurasial disposition in the north, together with the Phanerozoic, Paleo and Neotethyan territories, and the last tectonic movement, which continued until the end of the Middle Miocene period, starting in the Late 
Mesozoic, between the Arabian and Eurasial plates [9-12]. From the orogenic records, the Anatolian peninsula witnessed the development of large depressions by the beginning of the Cretaceous period and the Neotethyan suture zones include outcrop plains and valleys between mountains [12, 13]. Devonian units of different litho-types and of different paleogeographic origin are parts of thick Paleozoic sedimentary successions of the Pontides, Taurides and Arabian Plate. In the Taurides of Southern Turkey, it has been distinguished six different tectono-stratigraphic units: Geyikdağ Unit, Aladağ Unit, Bolkardağ Unit, Bozkır Unit, Alanya Unit and Antalya Unit [8, 14].

All along its geological past, Turkey has been located between the two mega-continents: Gondwana to the south and Laurasia to the north. It is generally accepted that numerous continental fragments belonging to one of these mega-continents were drifted off from the main body and amalgamated to the next so that the Anatolian realm is made of several oceanic and continental "terranes" with different geological features. The last main orogenic event, the Alpine orogeny, related to the closure of various Neotethyan branches directly controls the present distribution of these terranes. Southeast Anatolian Zone unit is the northern promontory of the Arabian Platform, which mainly consists of a pan African basement and its Paleozoic-Tertiary cover [15]. Southeast Anatolian Zone is separated from the northerly located Bitlis Unit by an active thrust zone, known as "Southeast Anatolian Fold and Thrust Belt" which can be traced south-eastward for hundreds of km's (Zagros Fold and Thrust Belt). The pre-Cambrian metamorphic basement of Southeast Anatolian Zone is locally observed in Southeast Anatolia [16, 17]. It includes andesitic and rhyolitic lavas and pyroclastics with bimodal chemistry, alternating with fluvial-deltaic type red clastic rocks and mudstones. This rift-related basement complex is transgressively overlain by quartz-arenites that grade into shelf type carbonates and nodular limestone of Middle Cambrian age [15, 18-25]. Southeast Anatolia region covers an area of $120,000 \mathrm{~km}^{2}$ and formed by rocky units from Cambrian to Miocene Eve. The Miocene sequences extend from Ergani and Hani in the north to Harran near the Syrian border in the south. In southern Turkey near Hazro, Hani and Çermik towns of Diyarbakır light and dark beige limestones (Frat formation) are very rich in fossil records.

Consequently, fossils belonging to Coelenterata, Bryozoa, Brachiopoda, Mollusca, Annelida, Echinodermata, Arthropoda and Hemichordata from invertebrate phyla were found in different parts of Turkey indicated Map 1. The map 1 mostly shows that the fossils belonging to the phyla of Mollusca and Echinodermata are found in the western part of Turkey, outside the region of Diyarbakir. This study reveals that the distribution of Echinodermata and Mollusca fossils in Turkey is also more southeastern. It is of great importance that there are not many studies related to the determinations of the fossils in the southeastern part of Turkey. Probably, with new investigations, marine fossils can be found in many places of Southeast Anatolia region. Approximately 36 million years ago, most of the Southeast Anatolia region was covered with seas. Later on, this sea took its present state about six million years ago by means of withdrawal of the Tethys Sea and shifting of the continents [5]. 


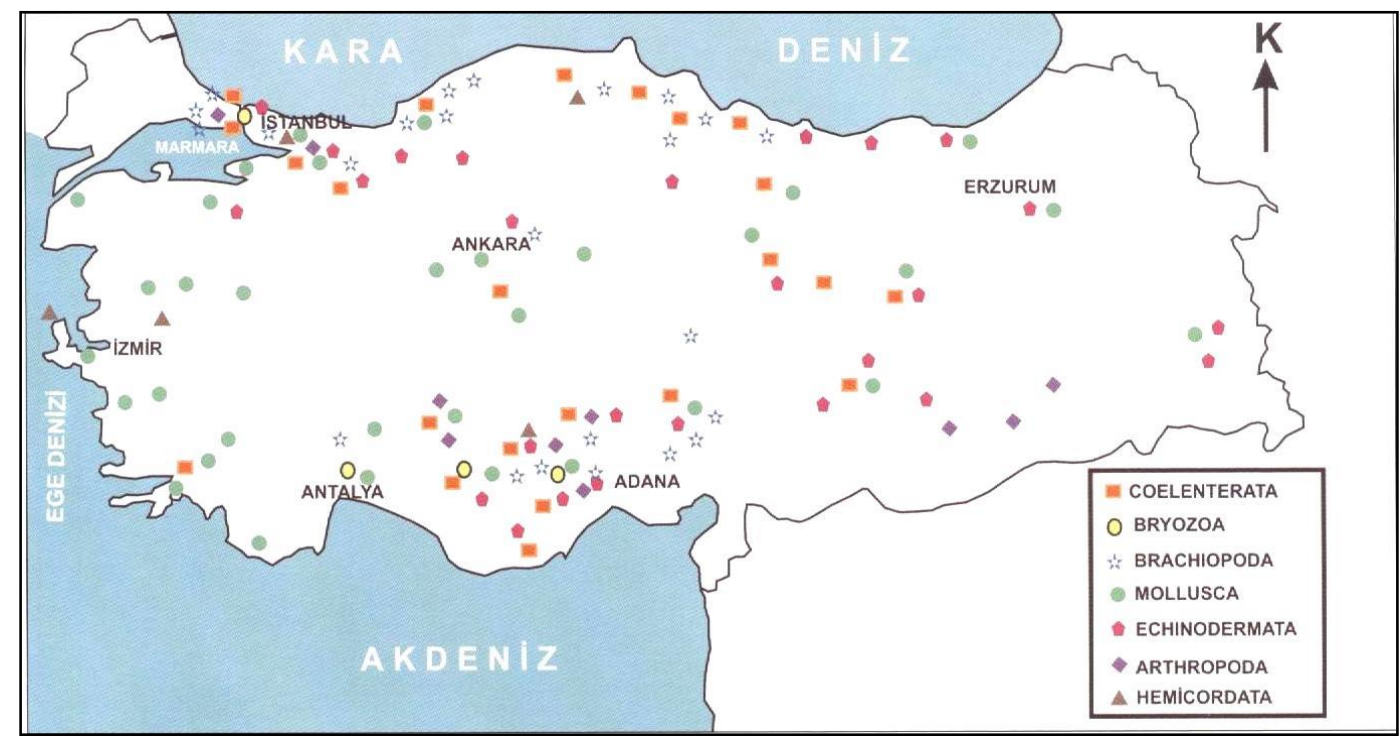

Map 1. Distribution of invertebrate fossils according to their phyla in Turkey [4]

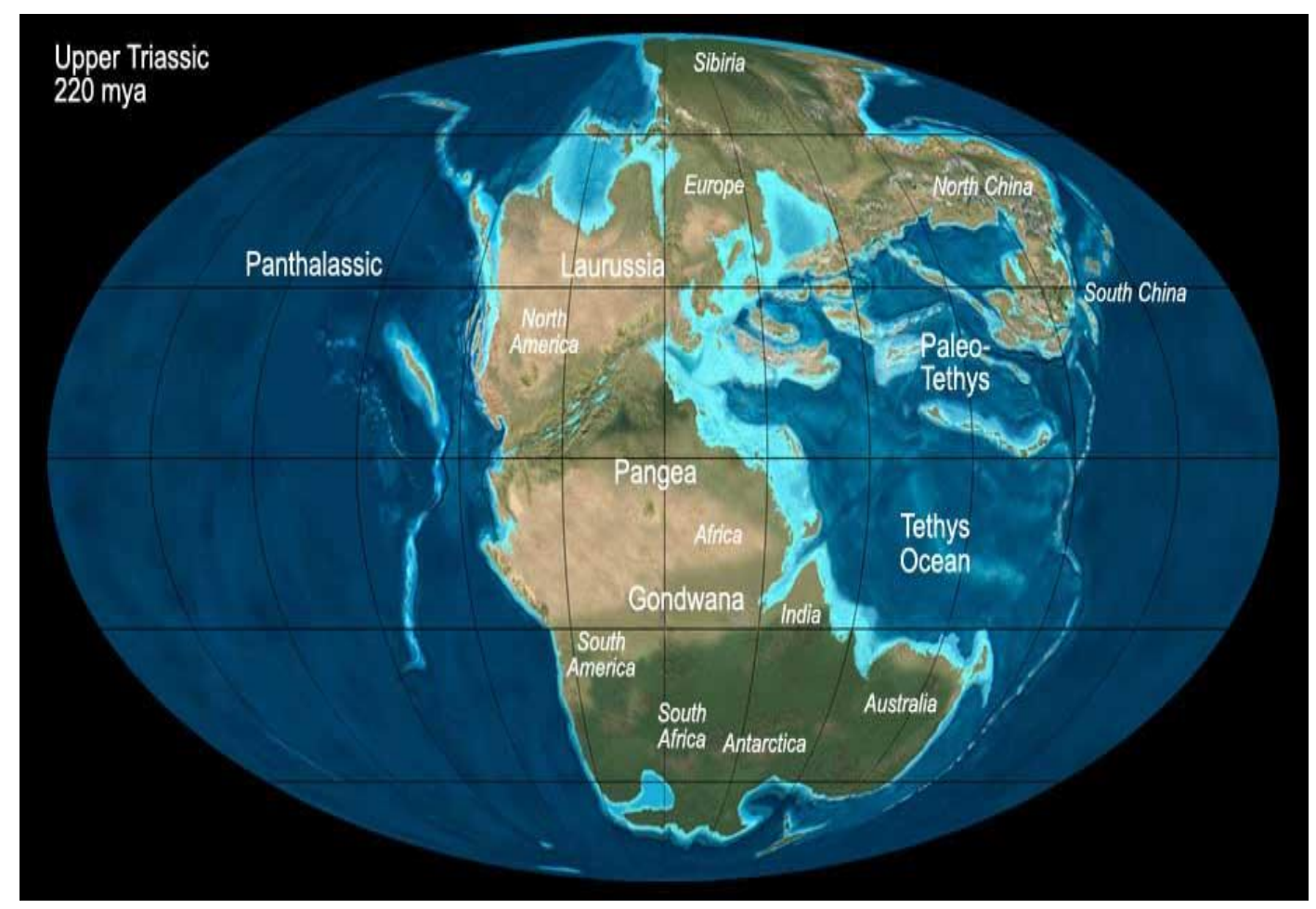

Map 2. Earth map: 220 million years ago. On the map, the remains of Anatolia and Laurasia, Gondwana continents have been indicated.(http://www.kerbtier.de/Pages/Themenseiten/enPhylogenie.html)

\section{References}

[1] Demirsoy, A., Basic Rules of Life. General Biology and General Zoology, Meteksan Inc., Ankara, 2005. 
[2] Cooper, J. D., Miller, R. H., Patterson, J., A Trip Through Time: Principles of Historical Geology, Merrill Publishing Company, London, 1986.

[3] Robetson, A. H. F., Dixon, J. E., "Introduction: Aspects of the geological evolution of the Eastern Mediterranean', Geological Society, London, Special Publications, 17, 1-74, 1984.

[4] İnan, N., Important Invertebrate Fossils of Turkey, Popular Science Books, TUBITAK, Ankara, 2008.

[5] Demirsoy, A., General Zoogeography and Turkey Zoogeography: Animal Geography, Meteksan Inc., Ankara, 2008.

[6] Salman, S., Invertebrate Biology, Palme Publishing, Ankara, 2006.

[7] Demirsoy, A., Inheritance and Evolution, Meteksan Inc., Ankara, 2008.

[8] Gourvennec, R., Hoşgör, İ., "Brachiopods and crinoids from the Middle-Upper Devonian boundary beds in the Darende-Gürün and Van-Zincirkıran areas (Eastern Taurus, Turkey)', Bulletin of Geosciences, 90(3), 577-600, 2015.

[9] Şengör, A. M. C., Y1lmaz, Y., "Tethyan evolution of Turkey: A plate tectonic approach", Tectonophysics, 75, 181-241, 1981.

[10] Bozkurt, E., Mittwede, S. K., "Introduction to the geology of Turkey - a synthesis", International Geology Review, 43, 578-594, 2001.

[11] Kaymakçı, N., İnceöz, M., Ertepınar, P., “3D architecture and Neogene evolution of the Malatya Basin: Inferences for the kinematics of the Malatya and Ovacik Fault Zones", Turkish Journal Earth Sciences, 15, 123-154, 2006.

[12] Özkurt, Ş. Ö., Güleç, E., Erkman, A. C., "Carnivores from the Late Miocene locality of Hayranlı (Hayranlı, Sivas, Turkey)", Turkish Journal of Zoology, 39, 842-867, 2015.

[13] Kaymakçi, N., Tectono-stratigraphical evolution of the Çankırı Basin (Central Anatolia, Turkey). Ph. D. thesis, Utrecht University, Utrecht, the Netherlands, 2000.

[14] Özgül, N., “Torosların bazı temel jeolojik özellikleri”, Türkiye Jeoloji Kurumu Bülteni, 19, 6578, 1976, (in Turkish).

[15] Sungurlu, O., “VI. Bölge kuzeyinin jeolojisi ve petrol imkanları', Proceeding of Türkiye İkinci Petrol Kongresi, Tebliğler, Ankara, Turkey, 1974, pp. 85-107, (in Turkish).

[16] Ketin, İ., “Güneydoğu Anadolu Paleozoyik teşekküllerinin jeolojik etüdü hakkında rapor (1. kısım: Derik-Bedinan, Penbeğli-Tut ve Hazro bölgesi)', TPAO Arama Grubu, 287, 1-36, 1964, (in Turkish).

[17] Ketin, İ., “'Güneydoğu Anadolunun Kambriyen teşekkülleri ve bunların Doğu İran Kambriyeni ile mukayesesi”, Maden Tetkik ve Arama Dergisi, 66, 75-87, 1966, (in Turkish).

[18] Schmidt, G. C., "'Stratigraphy of Lower Paleozoic rock units of petroleum distinct V-Turkey", Bulletin of Petroleum Administration Publication, 11, 73-90, 1966. 
[19] Dean, W. T., "Cambrian Stratigraphy and Trilobites of the Samur Dag Area, South of Hakkari, Southeastern Turkey”, Turkish Journal Earth Sciences, 15, 225-257, 2006.

[20] Demircan, H., Gürsu, S., "New trace fossils finding in Telbesmi Formation in Southeast Anatolian Autochton Belt (Turkey)", Proceeding of IPETGAS, Ankara, Turkey, 2009.

[21] Göncüoğlu, M. C., Kozlu, H., "Remarks on the pre-Variscan development in Turkey, Prevariscan Terrane Analyses of Gondwanean Europa" Proceedings of Schriften des Staatl Mus Min Geolology Dresden, Germany, Vol 9, 137-138, 1998.

[22] Göncüoğlu, M. C., Kozlu, H., "Early Paleozoic evolution of the NW Gondwanaland: Data from southern Turkey and surrounding areas", Gondwana Research, 3, 315-324, 2000.

[23] Göncüoğlu M. C., Turhan, N., "Geology of the Bitlis Metamorphic Belt', International Symposium on the Geology of the Taurus Belt, MTA Publication, 237-244, 1984.

[24] Göncüoğlu, M. C., Turhan, N., "Rock units and metamorphism of the basement and Lower Paleozoic cover of the Bitlis Metamorphic Complex, SE Turkey, Lower Paleozoic Evolution in Northwest Gondwana', Turkish Association Petroleum Geology Special Publications, 3, 75-81, 1997.

[25] Göncüoğlu, M. C., Kozlu, H., Dirik, K., "Pre-Alpine and Alpine terranes in Turkey: Explanatory notes to the terrane map of Turkey", Annales Géologiques des Pays Helleniques, 37, 515-536, 1997. 